\title{
ОСОБЕННОСТИ ОБУЧЕНИЯ РУССКОМУ ЯЗЫКУ КИТАЙСКИХ СТУДЕНТОВ, ОБУЧАЮЩИХСЯ ПО ПРОГРАММАМ ДВУХДИПЛОМНОГО ОБРАЗОВАНИЯ (ТЕХНИЧЕСКИЙ ПРОФИЛЬ)
}

\section{FEATURES OF TEACHING THE RUSSIAN LANGUAGE TO CHINESE STUDENTS ENROLLED IN TWO-DEGREE PROGRAMS (TECHNICAL PROFILE) \\ Li Ruomei}

Summary: The specificity of the author's work as teachers of the Russian language is that the faculty trains students of technical specialties: future builders, engineers, mechanics.

Keywords: technical specialty, two-degree program, Difficulty in learning terminology in Chinese audience.
$\Pi$ рограммы двухдипломного образования существуют в Шаньдунском гидротехническом институте с 2004-ого года и реализуются на международном факультете. Первая программа, на которую было набрано 32 студента, была запущена совместно с Российским государственным аграрным университетом МСХА имени К.А. Тимирязева. Сейчас на международном факультете обучается более 400 студентов, а количество российских вузов-партнёров увеличилось до трёх. Кроме Российского государственного аграрного университета MCXА имени К.А. Тимирязева студенты международного факультета могут обучаться в таких российских вузах, как Ивановский государственный химико-технологический университет и Национальный исследовательский московский государственный строительный университет.

Специфика нашей работы как преподавателей русского языка заключается в том, что на факультете обучаются студенты технических специальностей: будущие строители, инженеры, механики. Русский язык является для них средством получения высшего образования: обучаясь по двухдипломным программам, китайские студенты могут поехать в Россию после третьего курса и продолжить своё обучение по направлениям подготовки бакалавриата. Дипломы, полученные китайскими студентами в российских вузах, сертифицируются Министерством образования КНР, таким образом, студенты, прошедшие обучение на международном факультете Шаньдунского гидротехнического института, становятся
Ли Жомэй

преподаватель, доцент, Шаньдунский гидротехнический институт, Kитай, пр. Шаньдунь, г. Жичжао 47374351@q9.com

Аннотация: Специфика автора работы как преподавателей русского языка заключается в том, что на факультете обучаются студенты технических специальностей: будущие строители, инженеры, механики.

Ключевые слова: техническая специальность, двухдипломная программа, Сложность в изучении терминологии в китайской аудитории.

востребованными специалистами на родине. Возможность получить высшее образование за рубежом является сильной мотивацией для китайских студентов во время изучения русского языка, однако для большинства из них русский язык в первую очередь является языком дальнейшего обучения, поэтому студенты подходят к изучению языка с практической стороны: приоритетным для себя они выбирают подготовку к тестированию на Первый сертификационный уровень, так как наличие сертификата, подтверждающего владение русским языком на уровне В1, является необходимым условием для продолжения обучения в российском вузе. Лишь небольшое количество студентов рассматривают русский язык как средство общения, особенно в условиях отсутствия среды изучаемого языка и моноязыковой аудитории.

В связи с тем, что студенты колледжа получают профессию в течение трёхлетнего обучения в Китае, перед ними стоит сложная задача - усвоить русский язык в объёме Первого сертификационного уровня и изучить предметы специальности: инженерную картографию, физику, геодезию, инженерную геологию, гидрологию, гидромеханику гидротехнических сооружений, введение в архитектуру. Чтобы снизить учебную нагрузку на студентов руководством факультета было принято решение распределить изучение дисциплин следующим образом: большинство предметов специальности изучается на первых двух курсах, в то время как для изучения русского языка отводится 10 часов в неделю. За два года 
студенты усваивают русский язык в объёме Базового уровня. На третьем курсе русский язык является основным предметом, так как за это время им необходимо достичь Первого сертификационного уровня, чтобы подтвердить свою учебную компетентность в российских вузах. Количество часов русского языка возрастает до 26 в неделю, из них 2 часа отводится языку специальности (технический профиль). Такое распределение учебных часов мы считаем целесообразным, так как студенты к третьему курсу уже усвоили русский язык в достаточном объёме для работы с синтаксическими конструкциями научного стиля речи и языка специальности, и предлагаемый им для изучения объём лексического материала не превышает определенного минимума данного этапа подготовки, включая лишь те лексические единицы, которые иллюстрируют пройденный ими грамматический материал и соответствуют сформированной за два года обучения в колледже научно-технической базе [3: 121124].

Одной из трудностью во время обучения языку специальности является наличие большого количества новой лексики, которую нужно усвоить студентам перед тем, как приступать к работе с научно-техническими текстами. Как известно, при отборе лексики необходимо руководствоваться принципом прагматического подхода: «в процессе обучения учащийся должен получить только тот объём информации, который ему необходим для выживания и последующего продвижения в профессиональной сфере» [1: 411-415]. Перед преподавателем русского языка стоит задача отобрать актуальную для студентов-инженеров лексику. Для наших студентов актуальными ЛСГ являются: названия чертёжных инструментов (угольник, циркуль, измеритель, линейка, лекало, рейсшина), названия геометрических фигур и элементов (линия, угол, квадрат, круг, окружность, прямоугольник), названия химических веществ (водород, кислород, азот, железо, алюминий), названия физических величин (скорость, масса, плотность, сила, энергия, ускорение). Поскольку студенты нашего института получают гидротехнические инженерные специальности, в процессе подготовки актуальными становятся следующие группы слов: названия водных природных объектов (река, озеро, водоём, речное русло), названия водных сооружений (канал, водохранилище, резервуар, плотина), терминологическая лексика (гидравлика, гидроэнергетика, гидромелиорачия, гидрометрия).

Так как наши студенты обучаются русскому языку в Китае, преподаватели стараются ограничивать употребление родного языка на уроке и при объяснении новой лексики используют иллюстрации (рис.1). Например, студенты, обучающиеся на нашем факультете, проходят инженерно-техническую подготовку и работают с различными чертёжными инструментами, которые мы можем использовать на уроке русского языка. Я про- шу студентов писать русские названия на инструментах для того, чтобы они имели возможность каждый день видеть их и запоминать. Благодаря тому что студенты уже хорошо знают физику и химию, многие термины не нуждаются в переводе. Например, можно предъявить формулу кинетической энергии аудитории $\mathrm{P}=\mathrm{mv}$, и студенты поминают значение терминов масса и скорость. Таким образом, при предъявлении материала на уроках языка специальности мы опираемся на опыт студентов, полученный в школе и в нашем институте. Практика показывает, что те, кто хорошо справляется с программой колледжа, легче усваивают язык специальности технического профиля. Сложность в изучении терминологии в китайской аудитории заключается в различии фонетического устройства языка и отсутствии заимствований в китайском языке, например, носители европейских языков могут опираться на родной язык при изучении языка специальности в российских вузах, носители китайского языка этим преимуществом не обладают. Такие слова, как теория, практика, физика, математика, температура, энергия, инженер, изоляция, атом, формула и многие другие, не будут понятны китайским студентам при первом предъявлении, так как по-китайски они имеют совершенно другое фонетическое и графическое выражение: теория 理论 (lilun -лилунь) , практика 实践 (shijian-uu изянь), тезис 论题 (lunti-лунь $\mathrm{mu}$ ), температура 温度 (wendu-вэньду), энергия 能量 (nengliang - пэнлян), инженер 工程师 (gongchengshi - гун чэн ши) , изоляция 绝缘 体 (jueyuanti - цзюе юань mu), атом 原子 (yuanzi - юань изы), формула 公式 (gongshi - гун шu). Следовательно, студенты лучше понимают научные тексты на русском языке, если последние содержат формулы и технические обозначения. Они способны прочитать и понять текст, найти в нём главную информацию и законспектировать его. При изучении языка специальности мы обращаемся и к опыту изучения русского языка, например, после изучения глаголов движения, студенты обращают внимание на такие конструкции научного стиля речи, как что входит во что (в состав сложных веществ входят два и более элементов), что проходит как (реакция проходит даже при низкой температуре), что переходит во что (при нагревании вещество переходит в жидкое состояние). На наш взгляд, понимание переносных значений слов и умение их анализировать повышают интерес к изучению языка и устанавливает прочные ассоциативные связи, что облегчает усвоение лексики и лексических конструкций.

Во время обучения мы стараемся развивать интерес студентов к русскому языку не только как к инструменту для получения образования, но и как к явлению культуры. На факультете организуются внеклассные мероприятия, например, конкурс чтения вслух, конкурс русской каллиграфии. В ноябре 2019 года среди студентов мы провели конкурс каллиграфии, организованный китайской онлайн-платформой «Дом русского языка». В кон- 
курсе приняли участие китайские студенты, изучающие русский язык во многих известных университетах Китая (Хэйлунцзянский университет, Пекинский второй университет иностранных языков и др.). Студенты нашего факультета приняли участие в групповом конкурсе, в котором было предложено сформировать группу из 5 студентов, каждый из которых написал стихотворение С. Есенина «Ночь» на русском языке. В декабре 2019 года в конкурсе чтецов, организованном также онлайн-платформой «Дом русского языка», студенты прочитали стихотворение К. Симонова «Жди меня» (рис. 3), по результатам интернет-голосования они заняли первое место и выиграли денежный приз. Внеучебная деятельность знакомит учащихся с русской культурой и мотивирует на дальнейшее изучение русского языка и русской культуры.

\section{ЛИТЕРАТУРА}

1. Аникина М.Н. Динамика и статика в подходах к изучению языка специальности: Актуальные проблемы преподавания русского языка как иностранного в вузе. Материалы Третьей международной научно-методической конференции. Москва, МГИМО (У) МИД России. - М.: МГИмо Университет, 2014.

C. 411-415.

2. Осинцева-Раевская Е.А. Роль и место родного языка при изучении русского языка как иностранного: Вестник Балтийского федерального университета им. И. Канта. Серия: Филология, Педагогика, Психология. Калининград: Балтийский федеральный университет имени Иммануила Канта, 2014. С. $96-102$.

3. Полякова Ю.Д. Лексический аспект при обучении научному стилю речи и языку специальности иностранных учащихся: Вестник тульского государственного университета. Серия современные образовательные технологии в преподавании естественнонаучных дисциплин. Тула: Тульский государственный университет, 2019. С. 121-124.

4. Anikina M.N. Dinamika i statika v podhodah k izucheniju jazyka special'nosti: Aktual'nye problemy prepodavanija russkogo jazyka kak inostrannogo v vuze. Materialy Tret'ej mezhdunarodnoj nauchno-metodicheskoj konferencii. Moskva, MGIMO (U) MID Rossii. - M.: MGIMO Universitet, 2014. C. 411-415.

5. Osinceva-Raevskaja E.A. Rol' i mesto rodnogo jazyka pri izuchenii russkogo jazyka kak inostrannogo: Vestnik Baltijskogo federal'nogo universiteta im. I. Kanta. Serija: Filologija, Pedagogika, Psihologija. Kaliningrad: Baltijskij federal'nyj universitet imeni Immanuila Kanta, 2014. C. 96-102.

6. Poljakova Ju.D. Leksicheskij aspekt pri obuchenii nauchnomu stilju rechi i jazyku special'nosti inostrannyh uchashhihsja: Vestnik tul'skogo gosudarstvennogo universiteta. Serija sovremennye obrazovatel'nye tehnologii v prepodavanii estestvennonauchnyh disciplin. Tula: Tul'skij gosudarstvennyj universitet, 2019. C. 121-124.

(c) Ли Жомэй (47374351@qq.com).

Журнал «Современная наука: актуальные проблемы теории и практики» 